\title{
¿BOURDIEU, PEDAGOGO?*
}

Philippe Meirieu

Revolucionados ante la injusticia social y escolar, los pedagogos militantes han visto en Bourdieu un aliado, un interlocutor y un adversario. Análisis de estas raras relaciones.

Los pedagogos militantes han mantenido siempre estas raras relaciones con Pierre Bourdieu. Algunos, revolucionados por la injusticia social y escolar, están resueltos a romper los fatalismos y a permitir el acceso a los saberes y a los poderes que la Escuela de la República deja de lado; ellos han visto en él un aliado, un interlocutor, un adversario.

Los trabajos de Bourdieu nutren, en efecto, de manera particular y oportuna, la indignación constitutiva de la cual los pedagogos son portadores. $Y$ ante él, unos no pueden argüir sino modestas observaciones, mientras que otros, como los conservadores, intentan perturbar con algunas diatribas patéticas sobre los jóvenes víctimas del complot de los adultos que les enseñan a residir socialmente. De ahí que se deshagan de él, más aún, cuando sus dificultades escolares revelan la "incapacidad" intelectual.

La reproducción y Los herederos, permiten apoyar el discurso de los inconformes con sus sabios análisis. Entonces, quienes pasan por románticos revolucionarios, tienden a instrumentar su nostalgia y su ternura por los jóvenes con sus violentos discursos contra sus colegas; aquí los vemos arroparse con los "resultados científicos" para justificar sus prácticas inconformes.

El curso magistral encuentra su eficacia subordinada a las aptitudes formadas socialmente, lo que justifica el trabajo individualizado y los "métodos activos". La oferta cultural, libremente propuesta a la buena voluntad individual, devuelve a la desigualdad fundamental su poderío: he aquí lo que arruina la "pedagogía de la exhortación" e invita a imaginar métodos adaptados a cada uno y capaces de fomentar el acceso a las formas "liberadoras" de la cultura.

El pedagogo militante, inescrupuloso, no duda en enrolar a Bourdieu bajo su bandera y su retórica de denuncia. Sin embargo, algunas veces, va un poco más lejos y mira de cerca las perspectivas abiertas, como se advierte en algunas páginas, particularmente sugestivas, al final de Los herederos, que invitan a la reflexión sobre el carácter progresista de "una pedagogía racional".

Bourdieu casi no toca, en sus obras siguientes, el mismo tema, aunque en algunas necesariamente se entrevé. En ellas, se esfuerza por acusar todas las formas implícitas de y complicidad cultural que permiten seleccionar y promover a Los herederos. Con la llegada de "la pedagogía por objetivos" y de la "pedagogía de la maestría", la idea de una "pedagogía racional" tiene por fin un camino: señalar precisamente el resultado esperado

\footnotetext{
* Phiippe Meirieu. Filósofo y especialista en educación. Profesor de la Universidad de Lyon II. Publicado en Magazine Littéraire $\mathrm{N}^{0}$ 369, PP. 47-49, octubre 1998. Traducción: Álvaro Moreno Durán.
} 
por el estudiante, detallar las consignas, evitar todo llamado a la convivencia social, explicitar los criterios de evaluación, etc.

La interpelación de Bourdieu sobre "la indiferencia a las diferencias" (enunciado que se puede deducir de La distinción, obra que agudiza la mirada de los pedagogos a la vez que los pone en guardia contra todas las facilidades racionales) como factor esencial de selección de la escuela, explica la necesidad de aclarar "la pedagogía diferenciada": una atención a las adquisiciones y a las estrategias de aprendizaje de cada uno, no para aislarlo, sino para permitir que se eleven, súbitamente, por encima de las determinaciones sociales.

El tipo del estudiante abstracto de la igualdad republicana no está espontáneamente disponible al concepto kantiano de lo universal; él permite que se reencuentren entre ellos, como aquellos que disfrutan del "discreto encanto de la burguesía". La pedagogía diferenciada lo permitiría con esperanza, con una verdadera democratización del acceso a los saberes.

Ciertamente, los pedagogos han evolucionado. Se han dado cuenta de los efectos perversos del "diferencialismo". El tratamiento diferenciado a los estudiantes puede contribuir a la creación de nuevos guetos si no se acompaña de un voluntarismo obstinado sobre los objetivos y de un esfuerzo constante para ofrecer espacios de reencuentro y de expresión colectiva a todos los considerados "diferentes". Los pedagogos también han medido los límites de la "pedagogía racional". La claridad y la coherencia son esenciales también en pedagogía, y no se puede olvidar que todo aprendizaje es un acto libre de un sujeto en constitución y que la interpelación de esta libertad es tan importante como la creación de los medios que le permiten expresarse. Pero esto no es una razón para abolir la deuda de la mirada de Bourdieu ni para borrar las solidaridades que hasta ahora han sido esenciales.

Falta aclarar la mayor diferencia: Bourdieu no invita al fatalismo cuando describe los fenómenos poderosos que desaniman toda ligereza de la acción pedagógica. Al respecto, se habló de una "sociología estéril"; se denunció "la reunión de las denuncias revolucionarias y la invitación al inmovilismo". Los años han pasado y este juicio parece injusto: desde La miseria del mundo, es bien sabido que Bourdieu, finalmente, es tan literario como científico. Sin duda, está tan cerca de Zola como de Durkheim, de Flaubert como de Weber; su obra tiene un estilo, tiene un llamado a la compasión, una invitación a la ironía... y lo hace a través de una descripción estrictamente científica.

En este sentido, nada está restringido a los investigadores de las "ciencias humanas", al menos no lo esconde, y su talento es innegable. Cuando Bourdieu hablaba de la escuela, era casi un pedagogo; sienta las bases de un discurso sobre "la entrada", combinando descripciones y prescripciones, mirada distanciada y empeñada, evocación e indignación. Acepta así la vulnerabilidad de las ciencias humanas, en coherencia al peso de sus propias convicciones. 